\title{
MENINGKATKAN KEMAMPUAN PENALARAN MATEMATIK SISWA SMP MENGGUNAKAN PENDEKATAN PROBLEM POSSING MELALUI PEMBELAJARAN KOOPERATIF TIPE JIGSAW
}

\author{
Meicahyati ${ }^{1}$ \\ ${ }^{1}$ IKIP Siliwangi, Jl. Terusan Jendral Sudirman Cimahi, 40526 \\ Email penulis pertama: meicahyati182@gmail.com
}

\begin{abstract}
This research was to know the ability of mathematics reasoning of junior high school students. The research method that been used in this observation is the experiment method, it was because there was touched where there was one class which gets posing problem approach by jigsaw type model and another class gets common method. For mathematics reasoning the students used mathematics skill tes. The observational location of the researched was third grade of Budi Bhakti Utama junior high school Padalarang, the year of 2017/2018 education, that has 35 students. The process that been analyzed was the process of the students to answer for every question that measure mathematics reasoning indicator and also result of interview tes. The research give us the is better than a common method. We can see by the indicator question which be given on manipulation of mathematics and assumtion purpose. Check in the originality of argumentation. The students have the ability to answer and describe mathematics question and also give the reason for some solution that be given.
\end{abstract}

Keywords : mathematics reasoning, posing problem and jigsaw type learning

\begin{abstract}
Abstrak
Penelitian ini bertujuan untuk mengetahui kemampuan penalaran matematik siswa SMP. Metode penelitian yang digunakan adalah metode eksperimen, karena ada perlakuan dimana kelas yang satu memperoleh Pendekatan Problem posing melalui model pembelajaran tipe jigsaw dan kelas yang kedua mendapatkan metode pembelajaan biasa. Untuk kemampuan penalaran matematik siswa menggunakan tes uraian kemampuan penalaran matematik. Tempat penelitian dilaksanakan di SMP Budi Bhakti Utama Padalarang tahun ajaran 2017/2018 kelas VIII yang berjumlah 35 siswa. Proses yang dianalisis adalah poses jawaban siswa pada setiap soal yang mengukur indikator penalaran matematik dan hasil wawancara dengan siswa. Dari hasil penelitian diperoleh bahwa kemampuan penalaran matematik siswa SMP yang menggunakan pendekatan Problem possing melalui pembelajaran tipe jigsaw lebih baik daripada siswa yang mendapatkan pembelajaran menggunakan metode pembelajaan biasa. Dimana setiap indikator soal yaitu Mengajukan dugaan dan melakukan manipulasi matematika, Memeriksa kesahihan suatu argumen, Mengajukan dugaan dan melakukan manipulasi matematika, Mampu menyelesaikan soal tersebut dan mampu menggambarkan sketsa soal matematika, dan Kemampuan memberikan alasan terhadap beberapa solusi.
\end{abstract}

Kata kunci : Penalaran Matematik, Problem Posing dan Pembelajaran Tipe Jigsaw

Penalaran merupakan salah satu kompetensi dasar matematik disamping pemahaman, komunikasi, dan pemecahan masalah. Penalaran adalah proses berfikir yang dilakukan dengan satu cara untuk menarik kesimpulan. Kesimpulan yang bersifat umum dapat ditarik dari kasus-kasus yang bersifat individual. Tetapi dapat pula sebaliknya, dari hal yang bersifat individual menjadi kasus yang bersifat umum. Bernalar adalah melakukan percobaan didalam pikiran dengan hasil pada setiap langkah dalam untaian percobaan itu telah diketahui oleh penalar dari pengalaman tersebut. Sedangkan shurter dan pierce penalaran didefinisikan sebagai proses pencapaian kesimpulan logis berdasarkan fakta dan sumber yang relevan. 
Kemampuan matematik yang mencakup kemampuan untuk berfikir secara logis dan sistematis merupakan ranah kognitif matematis paling tinggi. Penalaran matematik memiliki peran penting dalam proses berpikir seseorang. Lehman (Lesnawati, 2010:9) meyebutkan manfaat lain dari penalaran, '1) Memperluas keyakinan (extending beliefe), 2) Menemukan kebenaran (getting at the truth), 3) Meyakinkan (persuading), 4) Menjelaskan (explaining)'.

Penalaran merupakan suatu proses penting dalam pengerjaan matematika. Ross (Mayasari, 2010:10) menyatakan, 'salah satu tujuan terpenting dari pembelajaran matematika yaitu mengajarkan kepada siswa penalaran logis (logical reasining). Bila kemampuan bernalar tidak dikembangkan kepada siswa, maka bagi siswa matematika hanya akan menjadi materi mengikuti serangkaian prosedur meniru contoh-contoh tanpa mengetahui maknanya.

Sumarmo (Kusnadi, 2010) memberikan indikator kemampuan yang termasuk pada kemampuan penalaran matematik, "1) menarik kesimpulan logis, 2) Memberikan penjelasan terhadap model, fakta, sifat dan hubungan, 3) Memperkirakan jawaban dan proses solusi, 4) Menggunakan pola dan hubungan menganalisis situasi matematik, 5) Membuat dan menyusun konjektur, 6) Merumuskan lawan contoh, 7) Mengikuti aturan inferensi, memeriksa validitas argument, 8) Menyusun argument yang valid, 9) Menyusun pembuktian langsung, pembuktian tak langsung dan menggunakan induksi amtematika.

Jadi kemampuan penalaran matematik yaitu kemampuan berpikir menurut alur kerangka berfikir tertentu berdasarkan konsep atau pemahan yang telah didapat sebelumnya, kemudian konsep atau pemahaman itu saling berhubungan satu sama lain dan diterapkan dalam permasalahan sehingga didapat keputusan baru yang logis dan dapat dibuktikan kebenarannya. Kemampuan penalaran matematik yang diukur dalam penelitian ini adalah 1) Memberi penjelasan terhadap model, fakta, sifat, dan hubungan, 2) Membuat dan menyusun konjektur, 3) mengikuti aturan inferensi, memeriksa Validitas argument, 4) Menyusun pembuktian langsung, pembuktian tak langsung dan menggunakan induksi matematika.

Adapun kelebihan pembelajaran dengan menggunakan pembelajaran kooperati tipe Jigsaw adalah sebagai berikut : 1) Mempermudah pekerjaan guru dalam mengajar, karena sudah ada kelompok ahli yang bertugas menjelaskan materi kepada rekan-rekannya, 2) Mengembangkan kemampuan siswa mengungkapkan ide atau gagasan dalam memecahkan masalah tanpa takut membuat salah. 3) Dapat meningkatkan kemampuan sosial, mengembangkan rasa harga diri dan hubungan interpersonal yang positif. 4) Siswa lebih aktif dalam berbicara dan berpendapat karena siswa diberikan kesempatan untuk berdiskusi dan menjelaskan materi pada masing-masing kelompok. 5) Siswa lebih memahami materi karena dipelajari lebih dalam dan sederhana dengan anggota kelompoknya. 6) Siswa lebih mampu menguasai materi yang diberikan karena mampu mengajarkan materi tersebut kepada teman sekelompoknya. 7) Siswa diajarkan bagaimana bekerja sama dengan kelompoknya. 8) Materi yang diberikan dapat merata. 9) Dalam proses belajar mengajar siswa saling ketergantungan positif. 
Untuk mengetahui motivasi belajar siswa sebelum diberi tindakan, terlebih dahulu tes awal sebagai bahan acuan pada pembentukan kelompok dan untuk melihat peningkatan prestasi belajar siswa. Prosedur penelitian tindakan kelas ini terdiri dari dua siklus dengan tiap siklus dilaksanakan sesuai dengan perubahan yang ingin dicapai pada faktor-faktor yang diselidiki. Pelaksanaan tindakan tersebut mengikuti prosedur penelitian tindakan kelas berikut, yaitu :Perencanaan, Pelaksanaan tindakan, Observasi dan evaluasi, Refleksi.

\section{METODE}

Penelitian ini merupakan penelitian eksperimen. Penelitian ini bemaksud untuk mengetahui penalaran matematik siswa SMP dalam menyelesaikan soal sistem persamaan linear dua variabel. Penelitian dilaksanakan pada bulan januari sampai dengan bulan maret tahun ajaran 2017/2018 di SMP Budi Bhakti Utama Padalarang, kelas VIII A dan VIII B yang masing-masing kelas berjumlah 35 siswa. Metode pengumpulan data yang digunakan dalam penelitian ini meliputi: Tes uraian yang digunakan untuk mengetahui kemampuan penalaran matematik siswa SMP.

Dan adapun desain penelitian yang akan digunakan sebagai berikut :

\section{$\mathrm{O} \quad \mathrm{x} \quad \mathrm{O}$}

$\mathrm{O} \quad \mathrm{O}$

Keterangan :

$\mathrm{O}$ : Pretest soal $=$ Posttes soal

$\mathrm{x}$ : Pembelajaran dengan pendekatan Problem Posing melalui pembelajaran kooperatif tipe Jigsaw

--- = Pengambilan sampel tidak secara acak.

\section{Teknik Analasis Data}

Tes yang digunakan dalam penelitian ini berupa soal-soal tes uraian. Tes uraian yang diberikan dalam bentuk pretes dan postes. Tujuan dilakukan pretes adalah untuk mengetahui kemampuan awal dari kelas kontrol dan kelas eksperimen. Sedangkan postes dilakukan setelah kedua kelas mendapatkan pembelajaran, bertujuan untuk mengetahui perbedaan peningkatan kemampuan komunikasi matematika yang dimiliki siswa setelah dilakukan pembelajaran.

Untuk mengetahui baik atau tidaknya instrumen yang akan digunakan maka instrumen diujicobakan terlebih dahulu dan kemudian diberi skor setelah diujicobakan. Adapun penskorannya adalah sebagai berikut : 
Tabel 1.1

Rubrik Penskoran

\begin{tabular}{|c|c|}
\hline Skor & Respon Siswa \\
\hline$\overline{0}$ & Tidak Ada Jawaban \\
\hline 1 & $\begin{array}{l}\text { - Jawaban tidak menggambarkan ide-ide matematik } \\
\text { - Kurang menggambarkan indicator kemampuan penalaran matematik } \\
\text { - Beberapa perhitungan salah } \\
\text { - Sedikit menggambarkan penalaran matematis } \\
\text { - Sudah ada upaya menjawab pertanyaan }\end{array}$ \\
\hline 2 & $\begin{array}{l}\text { - Beberapa jawaban tidak ada } \\
\text { - Menggambarkan indicator kemampuan penalaran matematik } \\
\text { - Tingkat pemikiran kurang tinggi } \\
\text { - Kesimpulan digambarkan tetapi kurang akurat } \\
\text { - Kesalahan kecil mungkin terjadi }\end{array}$ \\
\hline 3 & $\begin{array}{l}\text { - Jawaban benar tetapi kurang lengkap } \\
\text { - Menggambarkan indikator kemampuan penalaran matematis } \\
\text { - Hampir semua langkah jawaban benar } \\
\text { - Kesimpulan digambarkan secara lengkap } \\
\text { - Kesalahan kecil mungkin terjadi }\end{array}$ \\
\hline 4 & $\begin{array}{l}\text { - Jawaban lengkap dan benar } \\
\text { - Menggambarkan indikator kemampuan penalaran matematis } \\
\text { - Semua langkah benar } \\
\text { - Kesimpulan digambarkan secara lengkap } \\
\text { - Kesalahan kecil mungkin terjadi }\end{array}$ \\
\hline
\end{tabular}

\section{HASIL DAN PEMBAHASAN}

Berdasarkan hasil penelitian yang lakukan di lapangan disajikan sebagaimana Gambar 1 berikut dibawah ini : 


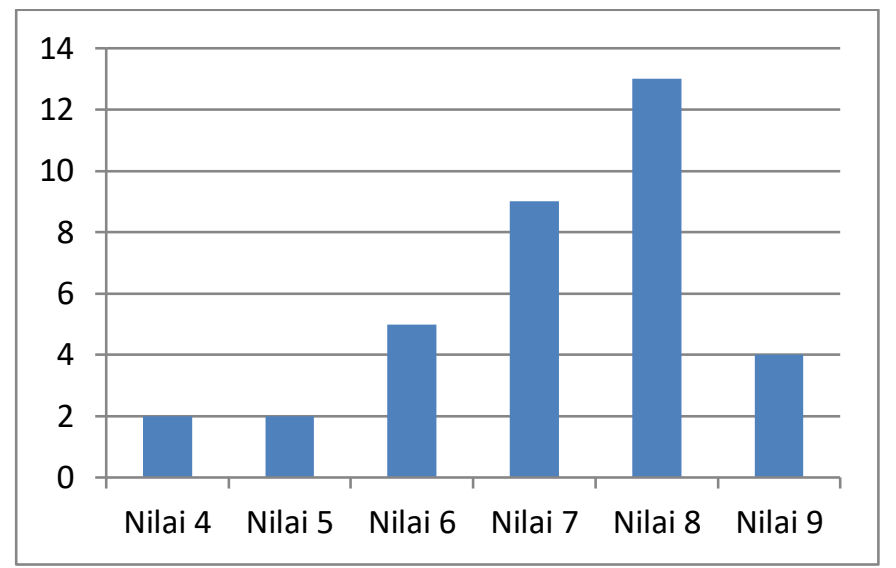

Gambar 1. Sebaran Nilai Kemampuan Penalaran Matematik

Selain itu, data nilai tersebut dapat pula dilihat melalui statistik nilai sebagaimana terlihat pada tabel 1.2 berikut di bawah ini :

Tabel 1.2

Statistik Nilai Kemampuan Penalaran Matematik

\begin{tabular}{|c|c|c|c|c|c|c|}
\hline$n$ & $\sum \mathrm{x}$ & $\sum \mathrm{x}^{2}$ & Rerata & Maks & Min & $\sigma$ \\
\hline 35 & 519 & 269361 & 14.83 & 19 & 8 & 2.66 \\
\hline
\end{tabular}

Untuk data lebih rinci, jawaban benar, salah dan tidak tahu dapat dilihat pada tabel 1.3 berikut :

Tabel 1.3

\section{Summary Jawaban Siswa}

\begin{tabular}{|c|c|c|c|c|c|}
\hline No Soal & 1 & 2 & 3 & 4 & 5 \\
\hline Jawaban Benar & $57,14 \%$ & $71,42 \%$ & $40 \%$ & $0 \%$ & $34,28 \%$ \\
\hline Jawaban Salah & $42,86 \%$ & $28,58 \%$ & $57,14 \%$ & $77,14 \%$ & $60 \%$ \\
\hline Tidak Tahu & $0 \%$ & $0 \%$ & $2,86 \%$ & $22,86 \%$ & $5,72 \%$ \\
\hline
\end{tabular}

Soal-soal yang digunakan dalam penelitian adalah sebagai berikut :

1. Harga satu buah molen dan dua buah pisang karamel adalah Rp. 6.000,00, sedangkan satu buah molen dan satu buah pisang karamel jenis yang sama Rp. 5.000,00. Hitunglah berapa uang yang harus dibayarkan jika membeli dua buah molen dan tiga pisang karamel?

2. Seorang pengrajin mebel dapat membuat tiga meja dan empat rak dengan papan kayu seluas $12 \mathrm{~m}^{2}$. papan kayu seluas $13 \mathrm{~m}^{2}$ dapat dibuat lima meja dan dua rak. Menurut Damar, satu meja 
membutuhkan $1 \mathrm{~m}^{2}$ papan dan satu rak membutuhkan 2,25 $\mathrm{m}^{2}$ papan. Sedangkan menurut Ema, satu meja membutuhkan $1,5 \mathrm{~m}^{2}$ papan dan satu rak membutuhkan $2,75 \mathrm{~m}^{2}$ papan. Apakah ada pendapat yang benar? Tuliskan pendapatmu!

3. Seorang pedagang telur ayam kampung dan telur ayam negeri telah menjual sebanyak 40 butir kedua jenis telur ini. Dari hasil penjualan 40 butir telur ayam tersebut, ternyata pedagang itu memperoleh uang sebanyak Rp. 10.750,00. jika harga sebutir telur ayam kampung itu Rp. 300,00 dan harga sebutir telur ayam negeri itu Rp. 175,00, berapa butir telur ayam kampung dan telur ayam negeri masing-masing yang terjual oleh pedagang itu?

4. Dua kali umur ayah dikurangi tiga kali umur Andi sama dengan 50 tahun. Sedangkan umur ayah jika ditambah dua kali umur Andi sama dengan 60 tahun. Buatlah model matematikanya dan selesaikan persoalan tersebut !

5. Seorang tukang parkir ditugasi menjaga tempat parkir untuk kendaraan motor dan mobil. Pada hari itu, tukang parkir tersebut telah memarkiri 32 kendaraan. Harga sewa untuk sekali parkir motor adalah Rp. 1000,00 dan untuk sekali parkir mobil adalah Rp. 2000,00. Dengan mendapatkan pendapatan sebesar Rp. 40.000,00 , periksa kebenaran apakah jumlah motor yang terparkir pada hari itu adalah 20 buah? Kemukakan alasanmu!

Dan adapun pembahasan dari tiap soal sebagai berikut :

1. Misal :

Molen $=\mathrm{x}$

Pisang karamel $=\mathrm{y}$

Persamaan yang didapat ;

$\mathrm{x}+2 \mathrm{y}=6000 \ldots($ persamaan 1$)$

$\mathrm{x}+\mathrm{y}=5000 \ldots($ persamaan 2$)$

Penyelesaian :

Nyatakan x dalam y :

$\leftrightarrow \mathrm{y}=5000-\mathrm{x}$

Subtitusikan ke persamaan 1

$\leftrightarrow \mathrm{x}+2 \mathrm{y}=6000$

$\leftrightarrow x+2(5000-x)=6000$

$\leftrightarrow \mathrm{x}+10000-2 \mathrm{x}=6000$

$\leftrightarrow-\mathrm{x}=-10000+6000$

$\leftrightarrow-\mathrm{x}=-4000$

$\leftrightarrow \mathrm{x}=4000$

Subtitusikan $\mathrm{x}=4000$ ke persamaan 2

$\leftrightarrow \mathrm{x}+\mathrm{y}=5000$ 


$$
\begin{aligned}
& \leftrightarrow 4000+\mathrm{y}=5000 \\
& \leftrightarrow \mathrm{y}=5000-4000 \\
& \leftrightarrow \mathrm{y}=1000
\end{aligned}
$$

Maka, jika membeli tiga buah molen dan dua buah pisang karamel uang yang harus dibayarkan adalah

$\leftrightarrow 3 \mathrm{x}+2 \mathrm{y}$

$\leftrightarrow 3(4000)+2(1000)$

$\leftrightarrow 12000+2000$

$\leftrightarrow 14000$

2. Misal :

Luas papan untuk meja $=\mathrm{M}$

Luas papan untuk rak $=\mathrm{R}$

Maka persamaan yang didapat yaitu :

$$
\left\{\begin{array}{l}
3 \mathrm{M}+4 \mathrm{R}=12 \\
5 \mathrm{M}+2 \mathrm{R}=13
\end{array}\right.
$$

Penyelesaiannya :

$$
\begin{array}{rr}
3 \mathrm{M}+4 \mathrm{R}=12 \times 1 & 3 \mathrm{M}+4 \mathrm{R}=12 \\
5 \mathrm{M}+2 \mathrm{R}=13 \times 2 & \frac{10 \mathrm{M}+4 \mathrm{R}=26}{-7 \mathrm{M} \quad=-14} \\
\hline & \frac{15 \mathrm{M}+20 \mathrm{R}=60}{14 \mathrm{R}=21} \\
\frac{15 \mathrm{M}+6 \mathrm{R}=39}{3 \mathrm{M}+4 \mathrm{R}=12 \times 5} & \mathrm{R}=\frac{3}{2} \text { atau } 1,5
\end{array}
$$

Diperoleh $\mathrm{M}=2$ dan $\mathrm{R}=1,5$

Jadi pendapat Damar dan Ema tidak benar. Karena untuk membuat satu meja membutuhkan papan $2 \mathrm{~m}^{2}$ dan untuk membuat satu rak 1,5m². Damar hanya melihat persamaan 1 dan Ema hanya melihat persamaan 2

3. Misalkan telur ayam kampung $=\mathrm{x}$ dan telur ayam negeri $=\mathrm{y}$

Karena jumlah telur-telur yang terjual itu 40butir maka diperoleh persamaan :

$\mathrm{X}+\mathrm{y}=40$

$300 x+175 y=10.750$ 
Untuk menyelesaikan persamaan diatas, digunakan metod eliminasi :

$$
\begin{aligned}
& X+y=40 \\
& 300 x+175 y=10.750 \quad \text { dikali } 1 \\
& \text { Maka : } \\
& 175 x+175 y=7000 \\
& \frac{300 x+175 y=10.750}{-125 x+0=-3.750}- \\
& -125 x=-3.750 \\
& \quad X=30
\end{aligned}
$$$$
\text { dikali } 175
$$

Jika nilai $\mathrm{x}=30$, disubtitusikan ke persamaan $\mathrm{x}+\mathrm{y}=40$, maka diperoleh :

$$
\begin{array}{r}
30+\mathrm{y}=40 \\
\mathrm{Y}=10
\end{array}
$$

Kesimpulannya :

Dari hasil perhitungan diatas maka banyaknya telur yam kampung yang terjual adalah 30butir dan telur ayam negeri 10butir.

4. Misal : umur Ayah $=m$

$$
: \text { umur Andi }=\mathrm{n}
$$

1. "Dua kali umur Ayah dikurangi tiga kali umur Andi sama dengan 50 yahun" dinyatakan dengan : $2 m-3 n=50$

2. "Umur ayah jika ditambah dua kali umur Andi sama dengan 60 tahun " dinyatakan dengan :

$m+2 n=60$

diperoleh persamaan :

$$
\begin{aligned}
& 2 m-3 n=50 \ldots(\text { persamaan } 1) \\
& m+2 n=60 \ldots(\text { persamaan } 2)
\end{aligned}
$$

Lakukan eliminasi :

$$
\begin{array}{rll}
2 m-3 n=50 & x 2 & 4 m-6 n=100 \\
m+2 n=60 & \times 3 m+6 n=180 \\
\hline & =280 \\
7 m & =40
\end{array}
$$

Lakukan subtitusi ke persamaan 2 :

$$
\begin{aligned}
\mathrm{m}+2 \mathrm{n} & =60 \\
40+2 \mathrm{n} & =60 \\
2 \mathrm{n} & =60-20 \\
\mathrm{n} & =\frac{20}{2}=10
\end{aligned}
$$

Jadi kesimpulannya umur ayah 40tahun dan umur Andi 10 tahun. 
5. Misalkan: Motor $=\mathrm{x}$

Mobil $=\mathrm{y}$

$$
\begin{aligned}
& x+y=32 \ldots(\text { persamaan } 1) \\
& 1000 x+2000 y=40000 \rightarrow x+2 y=40 \ldots(\text { persamaan } 2) \\
& x+y=32 \\
& \underline{x+2 y=40}- \\
& -y=-8 \\
& y=8 \\
& x+y=32 \\
& x+8=32 \\
& x=32-8 \\
& x=24
\end{aligned}
$$

jadi, jumlah motor yang terparkir pada hari itu bukan 20 buah tetapi ada 24 buah

\section{Pembahasan}

Berdasarkan tabel 1.2 dan gambar 1, kemampuan penalaran matematis siswa masih tergolong rendah. Walaupun sebagian besar siswa sudah mendapatkan nilai diatas kriteria ketuntasan minimum yaitu 6. ada 33 siswa yang nilainya diatas kriteria ketuntasan minimun dan 2 siswa yang nilainya masih dibawah kriteria ketuntasan minimum. Dalam penelitian metode yang digunakan yaitu Pendekatan Problem Posing melalui pembelajaran kooperatif tipe Jigsaw. Dimana para siswa dikelompokkan menjadi beberapa bagian untuk mengerjakan contoh soal pre test dan post test yang diberikan oleh guru.

Pada contoh soal no 4 dimana siswa dituntut untuk membayangkan dan mengira-ngira menggunakan penalarannya untuk dapat membuat model matematika dari soal yang telah diberikan. Sebanyak $77,14 \%$ siswa menjawab salah dan $22,86 \%$ tidak tahu atau tidak menjawab serta $0 \%$ siswa yang dapat menjawab. Hal ini menandakan bahwa siswa lebih mampu mengerjakan soal-soal yang sudah jelas jumlah dan angka-angkanya daripada soal-soal yang dimana menuntut siswa menggunakan penalaran matematik.nya. Akan tetapi dalam penelitian ada peningkatan kemampuan penalaran matematik dari yang belum diberi tindakan metode pendekatan pembelajaran dengan yang sudah mendapatkan tidakan metode pendekatan pembelajaran

\section{KESIMPULAN}

Pembelajaran dengan menggunakan pendekatan Problem Posing yang melalui pembelajaran tipe Jigsaw lebih efektif dan lebih mendorong siswa untuk semangat selama mengikuti proses belajar 
mengajar daripada menggunakan metode pembelajaran biasa serta siswa mampu menghidupkan proses belajar mengajar dengan mengungkapkan ide-ide, pendapat serta mampu mempresentasikan hasil dari soal-soal dalam pembelajaran sehingga diskusi pun terjadi. Dan pembelajaran menggunakan pendekatan Problem Posing terjadi peningkatan kemampuan penalaran matematik siswa menurut NCTM (2000: 341) menyebutkan bahwa, “ problem posing and problem solving led to a deeper understanding of both content and process". Pembelajaran yang melibatkan pendekatan problem posing dan problem solving akan memunculkan pemahaman dan kemampuan penalaran yang lebih baik terhadap materi dan proses pembelajaran.

\section{DAFTAR PUSTAKA}

Arikunto S. (1991). Prosedur Penelitian. Jakarta: Rineka Cipta.

Lesnawati (2010). Perbandingan Kemampuan Penalaran Matematik Siswa dengan Pendekatan Pembelajaran Berbasis Masalah.Skripsi. STKIP Siliwangi. Bandung: Tidak diterbitkan.

Mayasari (2010). Perbandingan Kemampuan Penalaran Matematik Siswa antara yang Pembelajaranya Menggunakan Strategi Think Talk Write (TTW) dengan yang Menggunakan Cara Biasa. Skripsi. STKIP Siliwangi. Bandung: Tidak diterbitkan.

Nana S. (1988). Dasar-Dasar Proses Belajar Mengajar. Bandung: Sinar Baru.

Rusefendi, E, T. (2006). Pengantar Kepada Membantu Guru Mengembangkan Kompetensinya Dalam Pengajaran Matematika untuk Meningkatkan CBSA. Bandung: Tarsito.

Roestiyah (2008). Strategi Belajar Mengajar. Jakarta: Rineka Cipta.

Slavin.E.R. (2005). Cooperative Learning Teori, Riset dan Praktik. London: Penerbit Nusa Media.

Suprijono A. (2009). Cooperative Learning. Yogyakarta: Pustaka Pelajar.

Rosnawati, R. (2013). Kemampuan Penalaran Siswa SMP Indonesia pada TIMSS 2011. In Prosiding Seminar Nasional Penelitian, Pendidikan dan Penerapan MIPA, Fakultas MIPA, Universitas Negeri Yogyakarta (vol. 18)

Ruseffendi, ET. (2010). Dasar-Dasar Penelitian Pendidikan \& Bidang Non- Eksakta Lainnya. Tarsito: Bandung. 